\title{
$\mathrm{W}$ の影響
}

\author{
石 井 不二夫**不破祏*2
}

\section{Effect of Alloying Element on the Solubility of Nitrogen in Liquid Iron}

Fujio IsHII and Tasuku FUwA

\section{Synopsis:}

Solubilities of nitrogen in liquid $\mathrm{Fe}-\mathrm{Ti}, \mathrm{Fe}-\mathrm{V}, \mathrm{Fe}-\mathrm{Cr}, \mathrm{Fe}-\mathrm{Mo}$, and $\mathrm{Fe}-\mathrm{W}$ alloys are determined in the temperature range of $1580^{\circ}$ to $1680^{\circ} \mathrm{C}$ by sampling method.

The results obtained show that addition of $\mathrm{Ti}, \mathrm{V}, \mathrm{Gr}, \mathrm{Mo}$, and $\mathrm{W}$ increases the solubility of nitrogen in liquid iron. The effects of alloying elements on the activity of nitrogen in liquid iron at $1580^{\circ} \mathrm{C}$ are expressed as follows:

$$
\begin{array}{ll}
\log f_{\mathrm{N}}^{\mathrm{Ti}}=-0.9[\% \mathrm{Ti}] & <0.15 \% \mathrm{Ti}, P_{\mathrm{N}_{2}}=0.04 \sim 0.17 \mathrm{~atm} \\
\log f_{\mathrm{N}}^{\mathrm{V}}=-0.10[\% \mathrm{~V}] & <6.5 \% \mathrm{~V} \\
\log f_{\mathrm{N}}^{\mathrm{Cr}}=-0.047[\% \mathrm{Cr}] & <9 \% \mathrm{Cr} \\
\log f_{\mathrm{N}}^{\mathrm{No}}=-0.009[\% \mathrm{Mo}] & <9 \% \mathrm{Mo} \\
\log f_{\mathrm{N}}^{\mathrm{W}}=-0.003[\% \mathrm{~W}] & <9 \% \mathrm{~W} .
\end{array}
$$

\section{1. 緒}

\section{言}

製錬過程において，溶鋼中に溶解した窒素は鋼材の性 質に種々の影響を与えるので，その溶製にあたり窒素を 除くためにも，末た窒素を合金元素として添加するため にも操業上種々の努力が払われている.

著者らは溶融 $\mathrm{Fe}-\mathrm{N}$ 系に打斿る物理化学的基礎資料を 得るため，まず溶鉄の窒素溶解度を測定することにより 間接法と SIEVERTS 法を比較検討し, その得失を明らか にした ${ }^{1)}$ その結果，より広い温度範囲に適用できる間 接法により 10 元素につき溶融鉄合金の空素溶解度を測 定して，溶鉄中窒素の活量係数におよ汸す合金元素の影 響を求める一連の研究1)2 を行つてきた。

本報告は，その後引き続き測定した溶融 $\mathrm{Fe}-\mathrm{Ti}, \mathrm{Fe}-$ $\mathrm{V}, \mathrm{Fe}-\mathrm{Cr}, \mathrm{Fe}-\mathrm{Mo}$ および $\mathrm{Fe}-\mathrm{W}$ 系の結果について報 告し，さらにこれまでの測定結果をまとめて検討したも のである.

\section{2. 実 験 方 法}

実験装置および実験操作は前報告1)2) で述べたので， その概略を述べる。

装置はガス精製装置と溶解装置からなつており，反応 管は外径 $60 \mathrm{~mm}$, 内径 $52 \mathrm{~mm}$, 長さ $500 \mathrm{~mm}$ の不透明

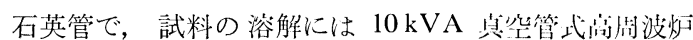
を使用した.

溶解試料には再電解鉄と合金元素を唒合して約 $100 \mathrm{~g}$ を用いた， $\mathrm{Fe}-\mathrm{N}-\mathrm{Ti}$ 系では $\mathrm{Ti}$ 濃度を少えて溶製した $\mathrm{Fe}-\mathrm{Ti}$ 合金を用い, その他の系では合全元素として市服 の純金属を添加した。また溶解用るつぼには㠼販の $\mathrm{Al}_{2} \mathrm{O}_{3}$ るつぼ（内径 $24 \mathrm{~mm}$, 高さ $50 \mathrm{~mm}$ ) を用いた。

実験操作は，まず試料を反応管内に設渞し，酸素を除 去するため約 $2 \mathrm{~h}$ 水素気流中で溶解する. その後， 1 $\mathrm{atm}$ の窒素または $P_{\mathrm{N}_{2}}$ を一定にした $\mathrm{N}_{2}-\mathrm{Ar}$ 泚合ガ久 気流（約 $150 \mathrm{ml} / \mathrm{min}$ ) 飞切り換兄て一定滥度汇保り, 溶融試料を窒素と平衡させる。平衡時阙を検㣙した結 果, $\mathrm{Ti}$ 系では 120 180 min, V 系では 180 240 min, $\mathrm{Cr}$, Mo と W の各系では 120 240 min とした. 平衡 到達後, 溶融試料の一部を内径約 $4 \mathrm{~mm}$ の不透明石英 管で吸引採取し水中急冷する。採取陚料中の空素定量に は酸溶解水蒸気蒸留一比色法, $\mathrm{Ti}$ と Mo には吸光光度 法，V と Cr には容量法，Wには重量法を用いた。测 定温度範囲は $1580^{\circ} \sim 1680^{\circ} \mathrm{C}$ である。

\section{3. 実 験 結 果}

溶融鉄合金中に窒素が窒化物を生成せずに溶解与る反 応式および平衡定数 $K$ は $(1) ，(2)$ 式で示される。また

顺和 50 作 4 月本会講演大会にて発表 睢利 56 年: 9 月 2 月受付 (Received Sept. 2, 1981)

* 東北大学工学被 工博 (Faculty of Engineering, Tohoku University, Aza-Aoba Aramaki Sendai 980)

*2 東北大学工学部(現：新日本製鉄 (株)) 工博 (Faculty of Engineering, Tohoku University, Now Nippon Steel Corp.) 
溶鉄中の窒素については SievERTS の法則が成立するの で，純鉄側の無限希沙浴液に活量の基準をとり，合金系 の見掛けの平衡定数を $K^{\prime}$ とすれば，窒素の活量係数に およぼす $\mathrm{j}$ 成分の影篥 $f \mathrm{j}$ は次のように求められる。

$$
\begin{aligned}
& 1 / 2 \mathrm{~N}_{2}=\mathrm{N} \quad \text { (in liquid iron alloys) } \\
& K=a_{\mathrm{N}} / V P_{\mathrm{N}_{2}}=[\% \mathrm{~N}] \cdot f_{\mathrm{N}}^{\mathrm{j}} / V P_{\mathrm{N}_{2}} \cdots \\
& K^{\prime}=[\% \mathrm{~N}] / V P_{\mathrm{N}_{2}} \cdots \ldots \ldots \ldots \ldots \ldots \ldots \ldots \ldots \ldots \ldots \ldots \ldots \ldots
\end{aligned}
$$$$
\log f_{\mathrm{N}}^{\mathrm{j}}=\log K-\log K^{\prime}
$$

ここで $[\% \mathrm{~N}]$ は合金中の窡素を重量百分率で表し， $\log K$ は $\mathrm{Fe}-\mathrm{N}$ 系につき間接法により温度依存性が求め られているので1)， 仓金系の測定温度と同一温度の值を 使用与る。

\section{(1) $\mathrm{Fe}-\mathrm{N}-\mathrm{Ti}$ 系}

$\mathrm{Ti}$ は窒化物を生成しやすい元素であるので $1 \mathrm{~atm} の$ 窒素は使用できない，それ故， $P_{\mathrm{N}_{2}}$ を $0.04 \sim 0.17 \mathrm{~atm}$ とした $1 \mathrm{~atm} の \mathrm{~N}_{2}-\mathrm{Ar}$ 混合ガスを用い, $1580^{\circ} \sim 1680$ ${ }^{\circ} \mathrm{C}$ で測定した。 また採取試料の窒素定量では酸不溶解 物質が諗められるので，残溘処理が必要である. Table 1 に测定結果を示し，Fig. 1 に $1680^{\circ} \mathrm{C}$ で測定した $[\% \mathrm{~N}]$ と $[\% \mathrm{Ti}]$ の閔係を亦す。溶融 $\mathrm{Fe}-\mathrm{Ti}$ 合金の窒 素溶解度は空化物が析出するまで $V P_{\mathrm{N}_{2}}$ に比例し， $[\%$ $\mathrm{Ti}$ 在增与と $[\% \mathrm{~N}]$ は著しく增加する。図中の黑丸点 は $1680^{\circ} \mathrm{C}, V P_{\mathrm{N}_{2}}=0.2$ における窒素の溶解度限で, $[\% \mathrm{Ti}]$ は $0.27 \%$ である. $1630^{\circ} \mathrm{C}, V P_{\mathrm{N}_{2}}=0.2$ では Table 1 に示すように窒素の溶解度限は $0.19 \% \mathrm{Ti}$ で

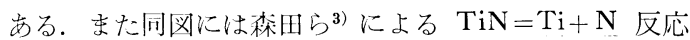
の絬果を図示したが，本研究結果に較べて森田らの窒素 溶解度限はわずかに [\% Ti] が高い側にある。Fig. 2 に $[\% \mathrm{Ti}]$ とその $\mathrm{Ti}$ 濃度における $K^{\prime}\left(=[\% \mathrm{~N}] / V P_{\mathrm{N}_{2}}\right)$ の関係を亦す。侨些した Ti 濃度の合金溶製が困難であ

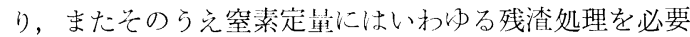

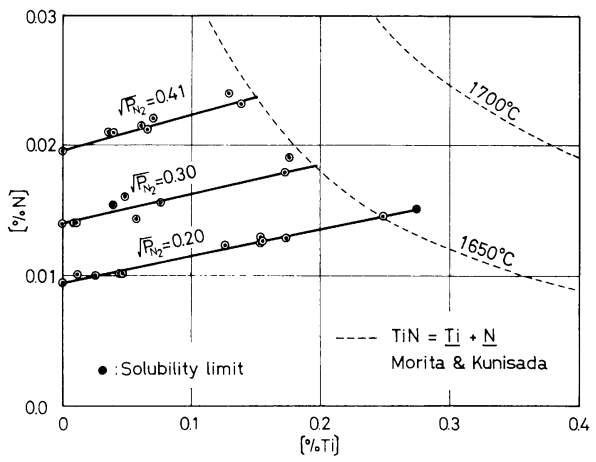

Fig. 1. Solubility of nitrogen in liquid irontitanium alloys at $1680^{\circ} \mathrm{G}$.
Table 1. Solubility of nitrogen in liquid Fe-Ti alloys.

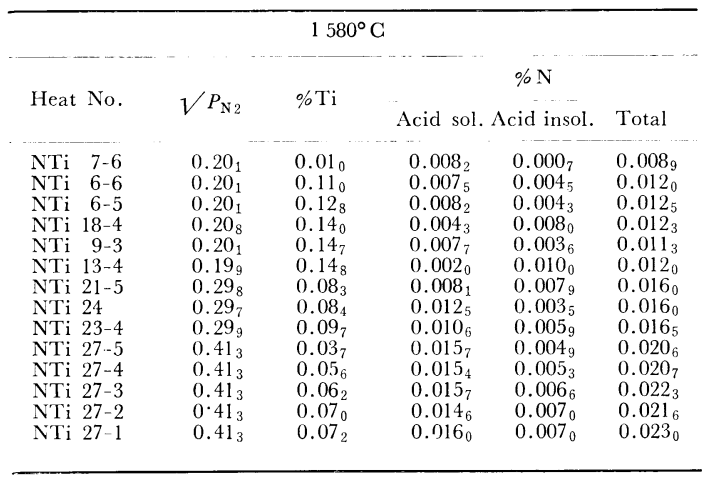

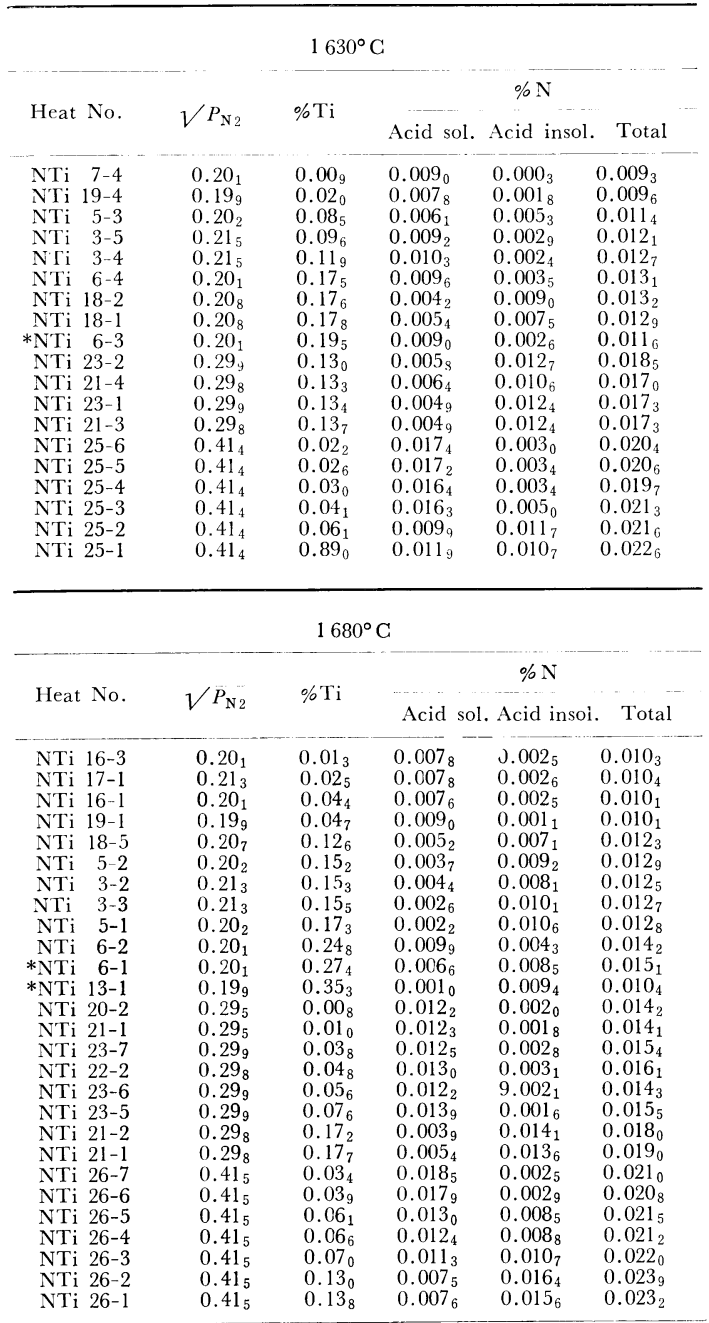

* Nitrides were precipitated.

とするため，望差が重なり测定俻のばらつきが涩められ る.これらの結果より Fig. 3 に $\log f_{\mathrm{N}}^{\mathrm{Ti}}$ と [\% $[\% \mathrm{Ti}]$ に つき図示すると，次の関係が得られる。 

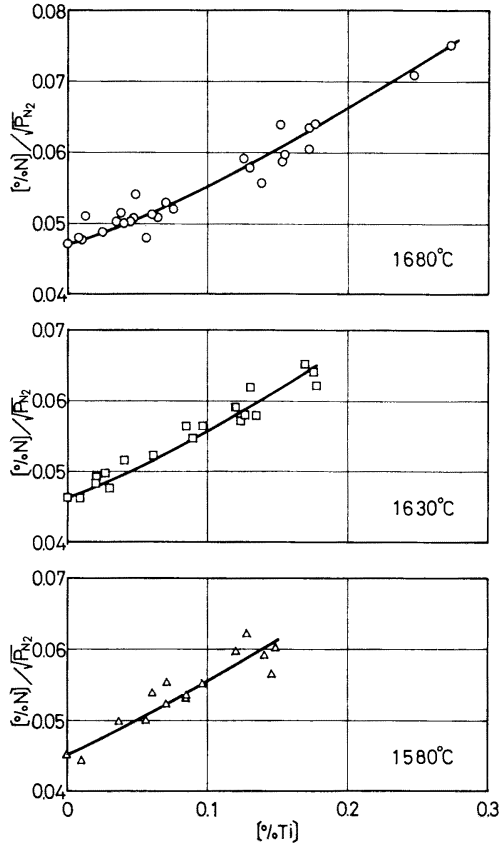

Fig. 2. Relation between $[\% \mathrm{~N}] / \sqrt{P_{\mathrm{N}_{2}}}$ and $[\% \mathrm{Ti}]$ in liquid iron.
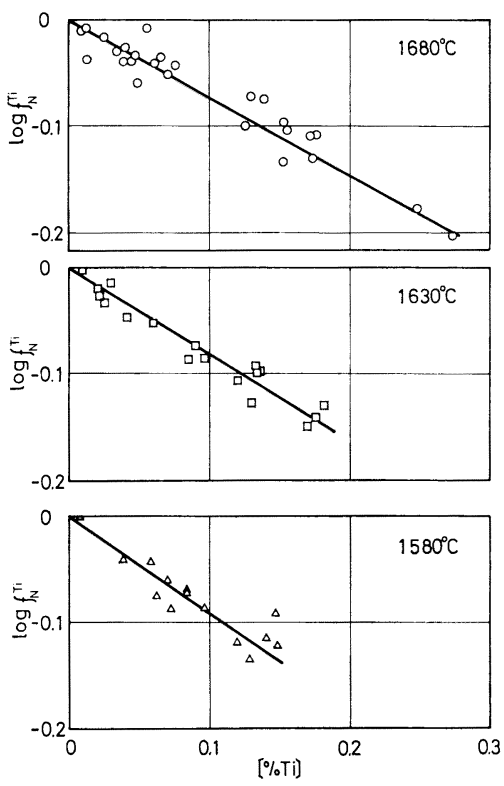

Fig. 3. Effect of titanium on the activity coefficient of nitrogen in liquid iron.

$$
\log f_{\mathrm{N}}^{\mathrm{Ti}}= \begin{cases}-0.70[\% \mathrm{Ti}] & \text { at } 1680^{\circ} \mathrm{C} \\ -0.80[\% \mathrm{Ti}] & \text { at } 1630^{\circ} \mathrm{C} \\ -0.90[\% \mathrm{Ti}] & \text { at } 1580^{\circ} \mathrm{C}\end{cases}
$$

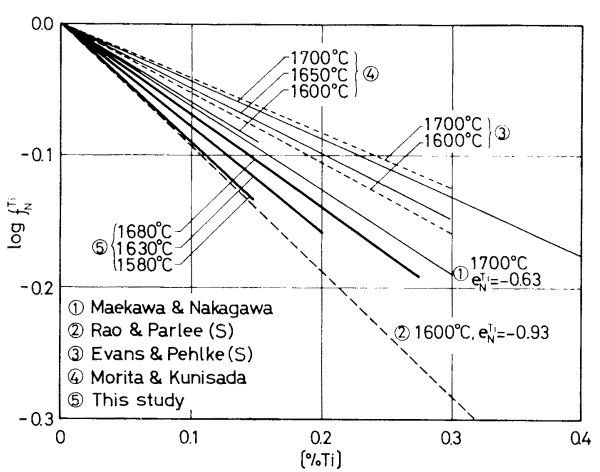

Fig. 4. Comparison of the effect of titanium on the activity coefficient of nitrogen in liquid iron.

$$
\begin{aligned}
& \log f_{\mathrm{N}}^{\mathrm{Ti}}=(-7240 / T+3.00) \cdot[\% \mathrm{Ti}] \\
& \ln r_{\mathrm{N}}^{\mathrm{Ti}}= \begin{cases}-144 N_{\mathrm{Ti}} & \text { at } 1680^{\circ} \mathrm{C} \\
-160 N_{\mathrm{Ti}} & \text { at } 1630^{\circ} \mathrm{C} \\
-176 N_{\mathrm{Ti}} & \text { at } 1580^{\circ} \mathrm{C}\end{cases}
\end{aligned}
$$

なお，本研究で求めた相互.作用孫数 $\left(\partial \ln r_{N} / \partial N_{\mathrm{j}}\right) N_{\mathrm{N}}$. $N_{\mathrm{j} \rightarrow 0}=\varepsilon_{\mathrm{N}}^{\mathrm{j}}$ はすべて原子分率に濃度変換して算出した估 である.

得られた結果を従来の測定結果と比較して Fig. 4 に 示す。 まず間接法による研究では, 前川ら4) $\mathrm{atm}, 1700^{\circ} \mathrm{C}$ に扎いて $0.3 \% \mathrm{Ti}$ まで測定し，相互作用 助係数 $d \log f_{\mathrm{N}} / d[\% \mathrm{Ti}]=e_{\mathrm{N}}^{\mathrm{T} \mathrm{i}}=-0.63$ を得た。 また森 田ら ${ }^{3)}$ は $P_{\mathrm{N}_{2}}$ を $0.04 \sim 0.36 \mathrm{~atm}, 1600^{\circ} \mathrm{C} \sim 1700^{\circ} \mathrm{C}$ で 測定し, 本研究結果より $\mathrm{Ti}$ の影嘅が小さい絬果を得て いる.

他方，Sieverts 法では RAO ら5) $P_{\mathrm{N}_{2}}$ が 0.0025 $1.0 \mathrm{~atm}, 1600^{\circ} \mathrm{C}$ で検討し，窒化物が析出しない範罒の 結果より $e_{\mathrm{N}}^{\mathrm{Ti}}=-0.93$ を得た。 また Evans ら6) は Fig. 4 に示すように森田ら ${ }^{3)}$ の值に近い結果を得ているが, 実測值のばらつきが大きく垫められる。本系のよらに $P_{\mathrm{N}_{2}}$ が小さい混合ガスを用いる测定に SIEVERTS 法を適 用することについては,なお検討の必要があると考える。

以上のごとく， Fe-N-Ti 系では窒素浴解度におよぼ 寸 $\mathrm{Ti}$ の影響が極めて大きく，乙かも测定濃度筑网が限 定されるため, 従来の結果を $1600^{\circ} \mathrm{C}$ の $e_{\mathrm{N}}^{\mathrm{Ti}}$ で比較す ると $-0.53 〜-0.93$ と大きな差違がある.

\section{(2) $\mathrm{Fe}-\mathrm{N}-\mathrm{V}$ 系}

本系については $P_{\mathrm{N}_{2}}$ を $0.09 \sim 1.0 \mathrm{~atm}, 1580^{\circ} \sim 1680$ ${ }^{\circ} \mathrm{C}$ の範囲で測定した. 測定結果を Table 2 に示し, $1580^{\circ} \mathrm{C}$ の結果を Fig. 5 に図示する。溶鉄中のVは窒 素溶解度を增加させ， $P_{\mathrm{N}_{2}}=1 \mathrm{~atm}, 1580^{\circ} \mathrm{C}$ では約 6.6 $\% \mathrm{~V}$ で窒化物が溶融試料主血に析出する。また浴融 $\mathrm{Fe}$ $-\mathrm{V}$ 合金中の窒素溶解度は SIEVERTS の法則に彷う. 
Table 2. Solubility of nitrogen in liquid $\mathrm{Fe}-\mathrm{V}$ alloys.

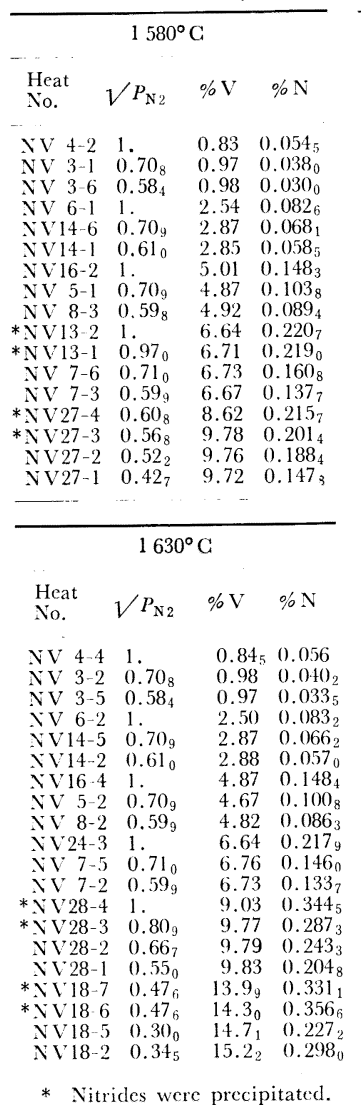

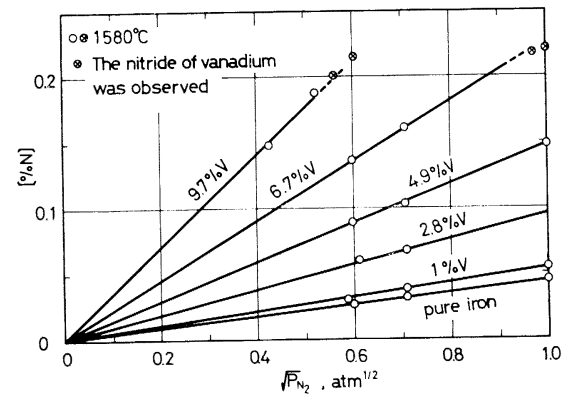

Fig. 5. Solubility of nitrogen in liquid ironvanadium alloys at $1580^{\circ} \mathrm{C}$.

$\log f_{\mathrm{N}}^{\mathrm{V}}$ と「\% 約 $7 \% \mathrm{~V}$ まで售緗闺係を示し, 温度の影響は明暸には認 められない.

$$
\begin{array}{ll}
\log f_{\mathrm{N}}^{\mathrm{v}}=-0.010\lceil \% \mathrm{~V}] & <6.5 \% \mathrm{~V} \\
\ln r_{\mathrm{N}}^{\mathrm{V}}=-21.2 N_{\mathrm{V}} & <0.07 N_{\mathrm{V}}
\end{array}
$$

Vの影秏については多くの测定結果が報告されてお り, 後述の Table 6 に比較するように間接法と SiE-

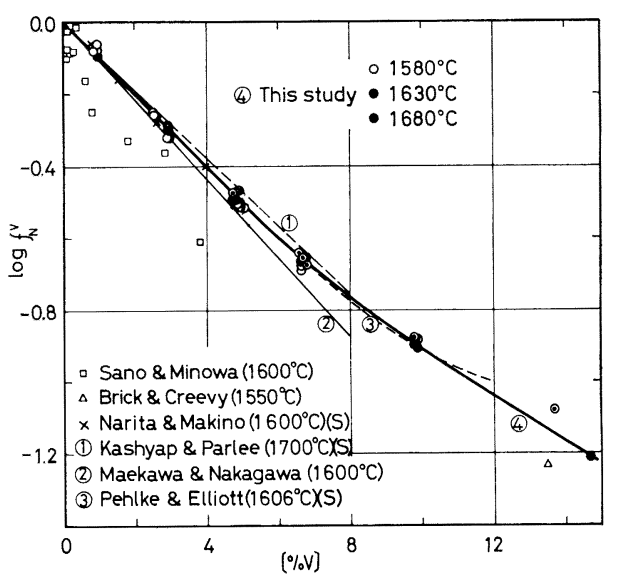

Fig. 6. Effect of vanadium on the activity coefficient of nitrogen in liquid iron at $1580^{\circ}-1680^{\circ} \mathrm{C}$.

VERTS 法による測定結果の差違は小さい。これは $P_{\mathrm{N}_{2}}=$ $1 \mathrm{~atm}$ 下で測定可能な範囲が広く，また $10 \% \mathrm{~V}$ 以下の 合金系ではVの蒸発も少ないためと考学られる，従来の 測定結果に基づく $e_{\mathrm{N}}^{\mathrm{V}}$ の值は $-0.09 \sim 0.11$ の範囲にあ り, 比較的一致している.

\section{(3) $\mathrm{Fe}-\mathrm{N}-\mathrm{Cr}$ 系}

$\mathrm{Fe}-\mathrm{N}-\mathrm{Cr}$ 系については $P_{\mathrm{N}_{2}}=1 \mathrm{~atm}, 1580^{\circ} \sim 1680^{\circ} \mathrm{C}$ の範囲で測定し，その結果を Table 3 および Fig. 7 に示す．Ｃｒ溶鉄の窒素溶解度を增加させる．各温度 に护る $\log f_{\mathrm{N}}^{\mathrm{Cr}}$ と [\% $[\% \mathrm{Cr}]$ について図示すると Fig. 8 のよらに約 $9 \% \mathrm{Cr}$ まで直線関係を示す. 温度の影響 については Table 3 に示すように, Cr 濃度が高くなる

Table 3. Solubility of nitrogen in liquid Fe-Gr alloys.

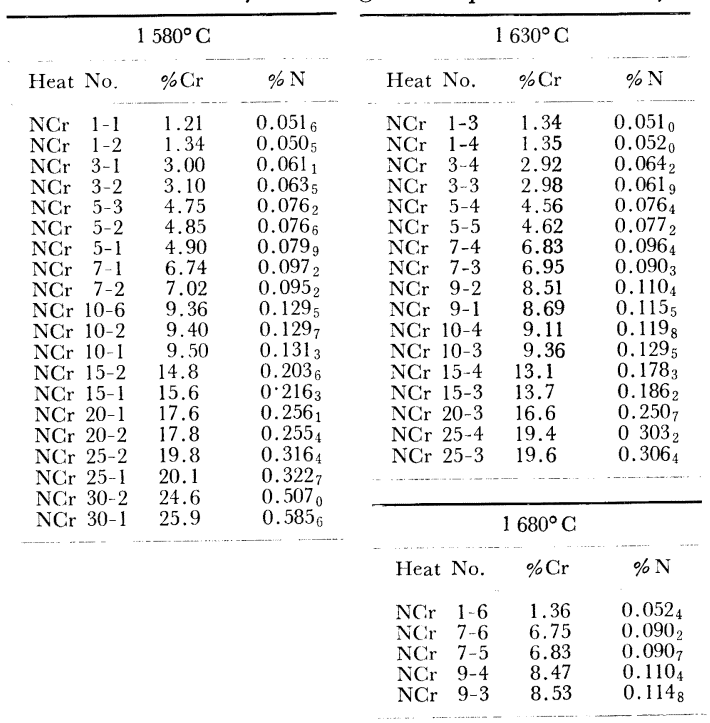




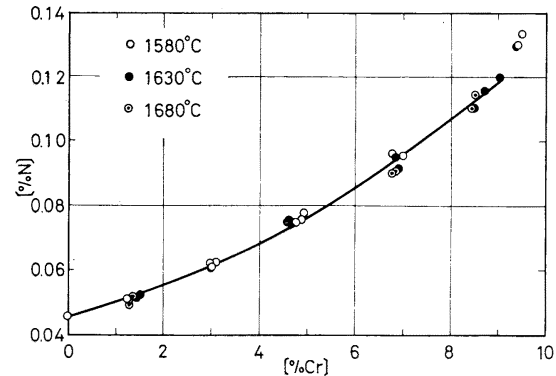

Fig. 7. Solubility of nitrogen in liquid ironchromium alloys.

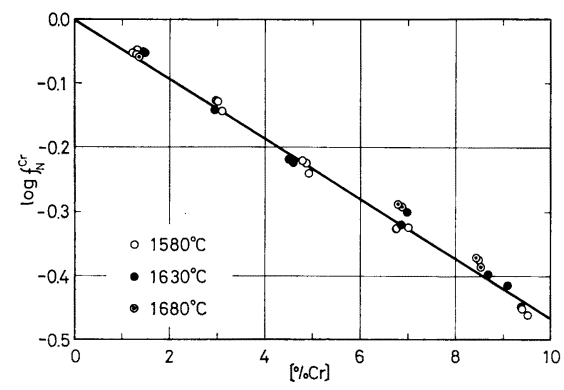

Fig. 8. Effect of chromium on the activity coefficient of nitrogen in liquid iron.

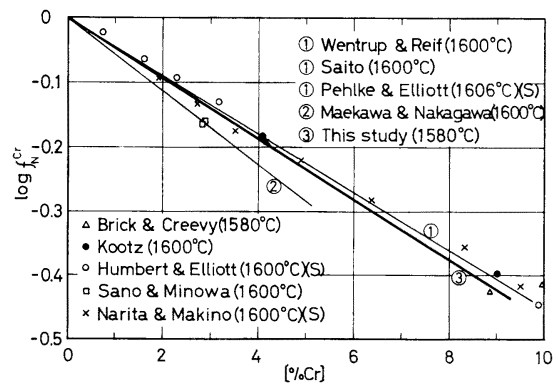

Fig. 9. Comparison of the effect of chromium on the activity coefficient of nitrogen in liquid iron.

と $1580^{\circ} \mathrm{C}$ の窒素溶解度は $1630^{\circ} \mathrm{C}$ の值よりわずかに 高值を示す。したがつて, 温度依存性は存在すると思わ れるが，本研究で測定した温度範囲からは温度の影響を 明らかにすることはできなかつた， $1580^{\circ} \mathrm{C}$ の測定值の 又をとれば次の関係が得られる。

$$
\begin{array}{ll}
\log f_{\mathrm{N}}^{\mathrm{Cr}}=-0.047[\% \mathrm{Cr}] & <9 \% \mathrm{Cr} \\
\ln r_{\mathrm{N}}^{\mathrm{Cr}}=-10.1 N_{\mathrm{Cr}} & <0.096 N_{\mathrm{Cr}}
\end{array}
$$

Cr の影響に関する研究は多く, 本研究結果と比較して Fig. 9 に図示する. 溶融 $\mathrm{Fe}-\mathrm{Cr}$ 系では $\mathrm{Cr}$ の蒸気压 が高く, $\mathrm{SAITO}^{19)}$ も報告しているように，約 $10 \% \mathrm{Cr}$ 以 上では Cr の蒸発減少が著しい。 それ故, SIEverts 法 で $\mathrm{Fe}-\mathrm{N}-\mathrm{Cr}$ 系を測定すると $\mathrm{Cr}$ 蒸気掞よびその窒素吸 収による誤差を含む可能性があるが，それにもかかわら
ず本系の $e_{\mathrm{N}}^{\mathrm{Cr}}$ は本研究結果を含めて $-0.044 \sim-0.048$ とよく一致している。しかし， Cr が 10\%以上の合金 系の測定に SIEVERTs 法を適用することは不適当である.

(4) Fe-N-Mo 系

本系では $P_{\mathrm{N}_{2}}=1 \mathrm{~atm}, 1580^{\circ} \sim 1680^{\circ} \mathrm{C}$ の籁明で測定 した，本系の採取試料は酸に溶解しにくいので，窒素定 量では特に試料の酸溶解に十分留意した。 その測定結果 を Table 4 およびFig. 10 に示す. Moは溶鉄の窒素溶

\begin{tabular}{|c|c|c|c|c|c|}
\hline \multicolumn{3}{|c|}{$1580^{\circ} \mathrm{C}$} & \multicolumn{3}{|c|}{$1630^{\circ} \mathrm{C}$} \\
\hline Heat No. & $\% \mathrm{Mo}$ & $\% N$ & Heat No. & $\% \mathrm{Mo}$ & $\% \mathrm{~N}$ \\
\hline $\begin{array}{l}\text { NMo } 1-4 \\
\text { NMo } 1-1 \\
\text { NMo } 3-4 \\
\text { NMo } 5-1 \\
\text { NMo } 5-2 \\
\text { NMo } 7-4 \\
\text { NMo } 9-1\end{array}$ & $\begin{array}{l}0.98 \\
1.01 \\
2.96 \\
5.01 \\
5.17 \\
7.02 \\
9.02\end{array}$ & $\begin{array}{l}0.046_{0} \\
0.046_{4} \\
0.048_{1} \\
0.050_{0} \\
0.050_{9} \\
0.053_{2} \\
0.055_{6}\end{array}$ & $\begin{array}{l}\text { NMo } 1-2 \\
\text { NMo } 5-3 \\
\text { NMo } 7-2 \\
\text { NMo } 9-2 \\
\text { NMo } 9-3\end{array}$ & $\begin{array}{l}1.00 \\
5.14 \\
6.60 \\
9.01 \\
9.08\end{array}$ & $\begin{array}{l}0.046_{9} \\
0.051_{4} \\
0.052_{7} \\
0.056_{1} \\
0.056_{3}\end{array}$ \\
\hline & $680^{\circ} \mathrm{C}$ & & & & \\
\hline Heat No. & $\% \mathrm{Mo}$ & $\% \mathrm{~N}$ & & & \\
\hline $\begin{array}{ll}\text { NMo } & 1-5 \\
\text { NMo } & 3-3 \\
\text { NMo } & 5-4 \\
\text { NMo } & 7-3 \\
\text { NMo } & 9-4\end{array}$ & $\begin{array}{l}1.02 \\
3.22 \\
5.18 \\
6.59 \\
9.03\end{array}$ & $\begin{array}{l}0.047_{3} \\
0.049_{5} \\
0.051_{3} \\
0.053_{8} \\
0.058_{0}\end{array}$ & & & \\
\hline
\end{tabular}
解度を増加させるが， $\log f_{\mathrm{N}}^{\mathrm{Mo}}$ と $[\% \mathrm{Mo}]$ の関係では Fig. 11 亿図示するように温度の影響は認められない.

Table 4. Solubility of nitrogen in liquid Fe-Mo alloys.

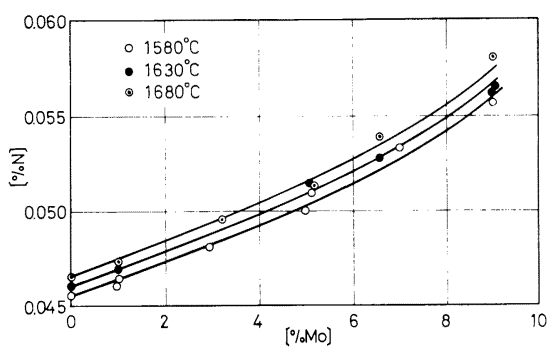

Fig. 10. Solubility of nitrogen in liquid ironmolybdenum alloys.

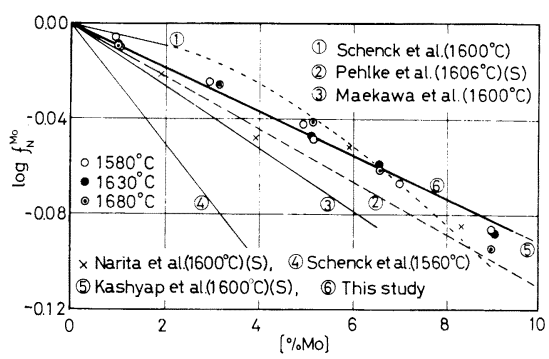

Fig. 11. Effect of molybdenum on the activity coefficient of nitrogen in liquid iron at $1580^{\circ}$ $1680^{\circ} \mathrm{C}$. 
$\log f_{\mathrm{N}}^{\mathrm{No}}=-0.009[\% \mathrm{Mo}] \quad<9 \% \mathrm{Mo}$

$\ln r_{\mathrm{N}}^{\mathrm{Mo}}=-4.6 N_{\mathrm{Mo}}$

$<0.054 N_{\mathrm{Mo}}$

Fe-N-Mo 系の過去の研究には, Sieverts 法による Kashyap ら ${ }^{11)}$ PehlKe ら ${ }^{13)}$ および成田ら ${ }^{15)}$ の測定結果 があり，後述の Table 6 と Fig. 11 に比較するよ5 に, これらの $e_{\mathrm{N}}^{\mathrm{M} \circ}$ は $-0.009 \sim-0.012$ である.

他方，間接法では，前川ら ${ }^{12)}$ および GunJI ら $e_{\mathrm{N}}^{\mathrm{M} \circ}$ として -0.013 を得ているが, 繰り返し測定した

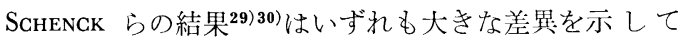
いる.この差違は試料中の窒素定量などの測定䛊差によ るものと推察される. 従来の測定結果に基づく $e_{\mathrm{N}}^{\mathrm{M}}$ はー 0.009 〜 0.013 の範囲にある.

\section{(5) $\mathrm{Fe}-\mathrm{N}-\mathrm{W}$ 系}

$\mathrm{Fe}-\mathrm{N}-\mathrm{W}$ 系の $1580^{\circ} \mathrm{C}$ に抢ける測定結果を Table 5 および Fig. 12 に示す.この系の採取試料もまた Fe-NMo 系の場合と同じく, 酸に難溶性であるので窒素定量 は容易でなく, 测定值にばらつきが認められる。Wは溶 鉄の窒素溶解度をわずかに增加させ, 窒素の活量係数に およぼす W の影響は Fig. 13 より次のように得られ た。

$$
\begin{array}{ll}
\log f_{\mathrm{N}}^{\mathrm{W}}=-0.003[\% \mathrm{~W}] & <9 \% \mathrm{~W} \\
\ln r_{\mathrm{N}}^{\mathrm{W}}=-4.6 N_{\mathrm{W}} & <0.029 N_{\mathrm{W}}
\end{array}
$$

本系については SieverTs 法による PehlKe ら ${ }^{13)}$ お よび成田ら ${ }^{15)}$ の研究があり, いずれも $e_{N}^{\mathrm{W}}$ 值として -0.002を報先している.

\section{4. 考察}

以上 5 種の 2 元系浴融鉄合金について，窒化物を生成

Table 5. Solubility of nitrogen in liquid Fe-W alloys.

\begin{tabular}{lccccccc} 
& \multicolumn{3}{r}{$1580^{\circ} \mathrm{C}$} & & & \multicolumn{3}{c}{$1580^{\circ} \mathrm{C}$} \\
\cline { 5 - 7 } Heat No. & $\% \mathrm{~W}$ & $\% \mathrm{~N}$ & & Heat No. & $\% \mathrm{~W}$ & $\% \mathrm{~N}$ \\
& & & & & & \\
NW 1 & 1.05 & $0.046_{1}$ & & NW 7-2 & 7.04 & $0.048_{1}$ \\
NW 3-2 & 2.98 & $0.047_{3}$ & & NW 7-1 & 7.10 & $0.047_{1}$ \\
NW 3-1 & 3.20 & $0.046_{1}$ & & NW 9 & 8.97 & $0.048_{6}$ \\
NW 5 & 5.33 & $0.047_{4}$ & & & &
\end{tabular}

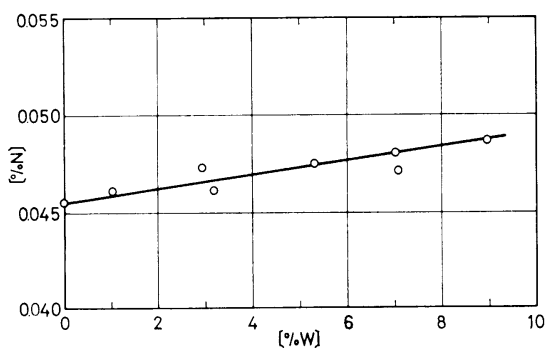

Fig. 12. Solubility of nitrogen in liquid irontungsten alloys.
しやすい系では Arを添加して $P_{\mathrm{N}_{2}}$ を低下させた 1 atm の混合ガスを用い，その他の系では窒素 1 atm にお ける窒素溶解度を測定し，溶鉄中の窒素の活量係数にお

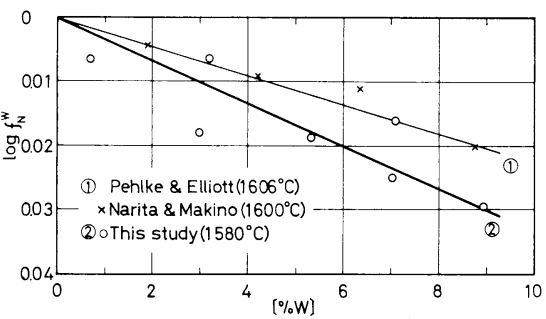

Fig. 13. Effect of tungsten on the activity coefficient of nitrogen in liquid iron at $1580^{\circ} \mathrm{C}$.

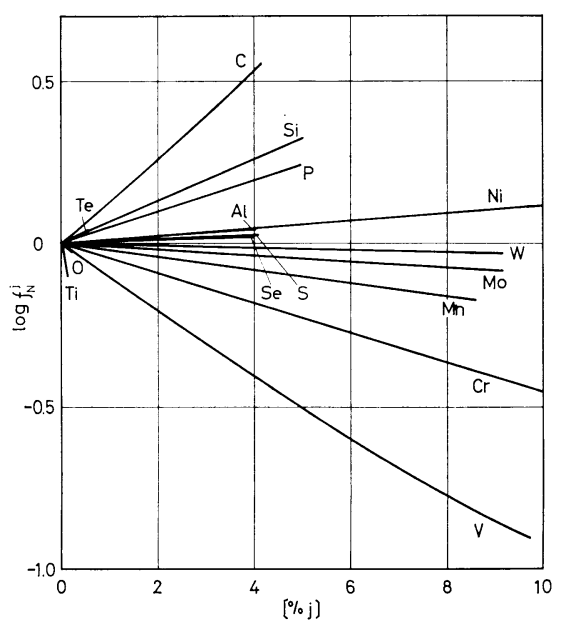

Fig. 14. Effects of alloying elements on $\log f_{\mathrm{N}}^{\mathbf{j}}$ in liquid iron at $1580^{\circ} \mathrm{C}$.

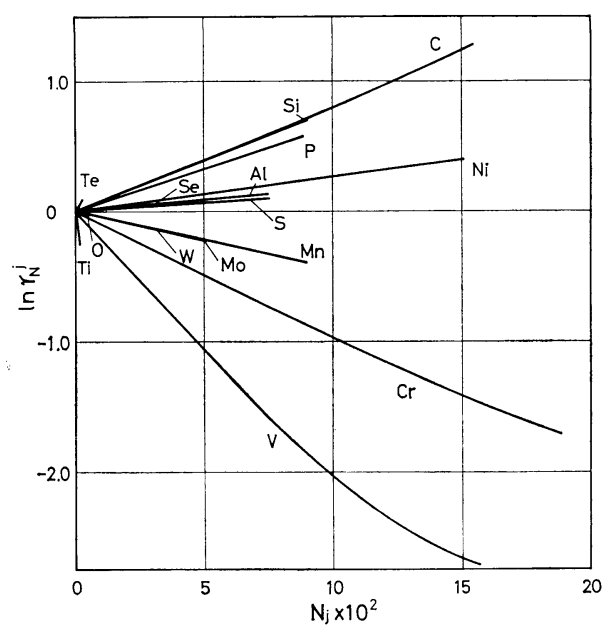

Fig. 15. Effects of alloying elements on $\ln r_{N}^{j}$ in liquid iron at $1580^{\circ} \mathrm{C}$. 
Table 6. Interaction parameters of nitrogen in liquid iron.

\begin{tabular}{|c|c|c|c|c|c|c|}
\hline \multirow[b]{2}{*}{$\begin{array}{l}\text { Element } \\
\mathrm{Ti}\end{array}$} & & $\begin{array}{c}\text { Ref. } \\
4 \\
5 \\
8\end{array}$ & $e_{\mathrm{N}}^{\mathrm{j}}$ & \multirow[b]{2}{*}{$\begin{array}{r}\varepsilon_{N}^{j} \\
-124.1 \\
-183.3 \\
-34.6 \\
-51.1 \\
-104.4 \\
-82.7 \\
-53.1 \\
-104.4 \\
-118.2 \\
-96.5 \\
-86.6 \\
-177.4 \\
-157.7 \\
-137.9\end{array}$} & \multicolumn{2}{|c|}{ Ranges } \\
\hline & $\begin{array}{l}\text { MAEKaWA \& NaKaGaWa } \\
\text { RAO \& PaRLEE } \\
\text { MOROzov et al. } \\
\text { EVANS \& PEHLKE } \\
\text { Fischer et al. } \\
\text { MORIta \& KUnisada } \\
\text { This study }\end{array}$ & $\begin{array}{l}4 \\
5 \\
8 \\
6\end{array}$ & $\begin{array}{l}-0.63 \\
-0.93 \\
-0.176 \\
-0.260 \\
-0.53 \\
-0.42 \\
-0.27 \\
-0.53 \\
-0.60 \\
-0.49 \\
-0.44 \\
-0.90 \\
-0.80 \\
-0.70\end{array}$ & & $\begin{array}{l}0.3 \% \mathrm{Ti}, \\
0.8 \% \mathrm{Ti}, \\
0.42 \% \mathrm{Ti}, \\
0.41 \% \mathrm{Ti}, \\
0.3 \% \mathrm{Ti}, \\
0.3 \% \mathrm{Ti}, \\
0.3 \% \mathrm{Ti}, \\
0.3 \% \mathrm{Ti},\end{array}$ & $\begin{array}{l}1700^{\circ} \mathrm{C} \\
1600^{\circ} \mathrm{C},(\mathrm{S}) \\
1580^{\circ} \mathrm{C},(\mathrm{S}) \\
1675^{\circ} \mathrm{C},(\mathrm{S}) \\
1600^{\circ} \mathrm{C},(\mathrm{S}) \\
1650^{\circ} \mathrm{C},(\mathrm{S}) \\
1700^{\circ} \mathrm{C},(\mathrm{S}) \\
1600^{\circ} \mathrm{C}, \\
1600^{\circ} \mathrm{C} \\
1650^{\circ} \mathrm{C} \\
1700^{\circ} \mathrm{C} \\
1580^{\circ} \mathrm{C} \\
1630^{\circ} \mathrm{C} \\
1680^{\circ} \mathrm{C}\end{array}$ \\
\hline V & 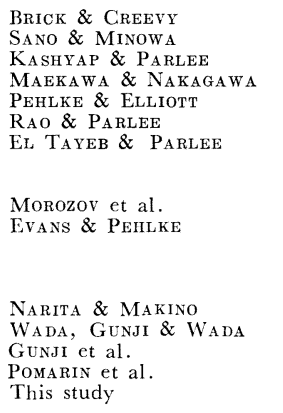 & $\begin{array}{c}10 \\
9 \\
11 \\
12 \\
13 \\
5 \\
14\end{array}$ & $\begin{array}{l}-0.09^{44} \\
-0.1945) \\
-0.095^{46} \\
-0.11 \\
-0.10 \\
-0.094 \\
-0.094 \\
-0.089 \\
-0.085 \\
-0.159 \\
-0.093 \\
-0.088 \\
-0.083 \\
-0.079 \\
-0.099 \\
-0.063 \\
-0.093 \\
-0.116 \\
-0.101\end{array}$ & $\begin{array}{l}-18.8 \\
-39.8 \\
-19.8 \\
-23.0 \\
-21.9 \\
-19.6 \\
-19.6 \\
-18.6 \\
-17.7 \\
-33.3 \\
-19.4 \\
-18.4 \\
-17.3 \\
-16.5 \\
-20.7 \\
-13.1 \\
-19.4 \\
-24.2 \\
-21.2\end{array}$ & $\begin{array}{l}13.5 \% \mathrm{~V}, \\
4 \% \mathrm{~V}, \\
10 \% \mathrm{~V}, \\
8 \% \mathrm{~V}, \\
6 \% \mathrm{~V}, \\
10 \% \mathrm{~V}, \\
10 \% \mathrm{~V}, \\
10 \% \mathrm{~V}, \\
10 \% \mathrm{~V}, \\
7.7 \% \mathrm{~V}, \\
15 \% \mathrm{~V}, \\
15 \% \mathrm{~V}, \\
15 \% \mathrm{~V}, \\
15 \% \mathrm{~V}, \\
5 \% \mathrm{~V}, \\
6 \% \mathrm{~V}, \\
11 \% \mathrm{~V}, \\
6.5 \% \mathrm{~V},\end{array}$ & 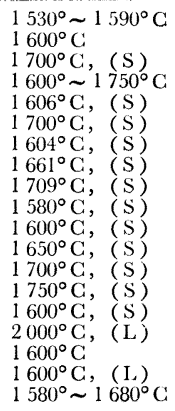 \\
\hline $\mathrm{Cr}$ & 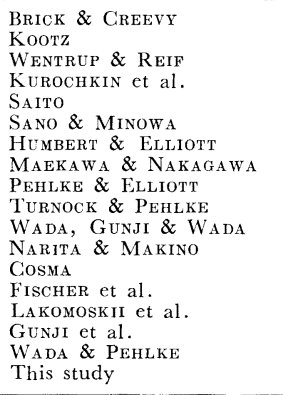 & $\begin{array}{c}10 \\
20 \\
21 \\
22 \\
19 \\
9 \\
23 \\
12 \\
13 \\
24 \\
25 \\
15 \\
26 \\
7 \\
27 \\
17 \\
28\end{array}$ & $\begin{array}{l}-0.045 \\
-0.045 \\
-0.045 \\
-0.025 \\
-0.045 \\
-0.048 \\
-0.045 \\
-0.057 \\
-0.045 \\
-0.0468 \\
-0.032 \\
-0.047 \\
-0.0459 \\
-0.044 \\
-0.042 \\
-0.043 \\
-0.046 \\
-0.047\end{array}$ & $\begin{array}{l}-9.57 \\
-9.57 \\
-9.57 \\
=5.28 \\
-9.57 \\
-10.2 \\
-9.57 \\
-12.1 \\
=9.57 \\
=9.95 \\
=6.7 \\
-10.0 \\
=9.76 \\
-9.35 \\
-8.93 \\
-9.14 \\
-9.78 \\
-10.1\end{array}$ & $\begin{array}{l}10 \% \mathrm{Cr}, \\
9.5 \% \mathrm{Cr} \\
10 \% \mathrm{Cr}, \\
3 \% \mathrm{Cr}, \\
3 \% \mathrm{Cr}, \\
5 \% \mathrm{Cr}, \\
10 \% \mathrm{Cr}, \\
5 \% \mathrm{Cr}, \\
7 \% \mathrm{Cr}, \\
9.5 \% \mathrm{Cr}, \\
17 \% \mathrm{Cr}, \\
15 \% \mathrm{Cr}, \\
9 \% \mathrm{Cr},\end{array}$ & $\begin{array}{l}1580^{\circ} \mathrm{C} \\
1600^{\circ} \mathrm{C} \\
1600^{\circ} \mathrm{C} \\
1550^{\circ} \mathrm{C} \\
1560^{\circ} \sim 1650^{\circ} \mathrm{C} \\
1600^{\circ} \mathrm{C} \\
1600^{\circ} \mathrm{C} \text {, (S ) } \\
1600^{\circ} \sim 1700^{\circ} \mathrm{C} \\
1606^{\circ} \mathrm{C} \text {, (S) } \\
1600^{\circ} \mathrm{C} \text {, (S) } \\
\left.2000^{\circ} \mathrm{C} \text {, ( } \mathrm{L}\right) \\
1600^{\circ} \mathrm{C} \text {, (S) } \\
1600^{\circ} \mathrm{C} \\
1600^{\circ} \mathrm{C} \\
1600^{\circ} \mathrm{C},(\mathrm{L}) \\
1600^{\circ} \mathrm{C}, \\
1600^{\circ} \mathrm{C},(\mathrm{S}) \\
1580^{\circ} \mathrm{C}\end{array}$ \\
\hline Mo & 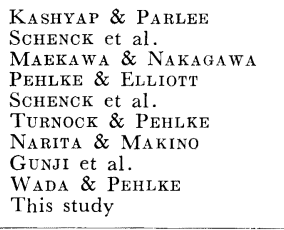 & $\begin{array}{l}11 \\
29 \\
12 \\
13 \\
30 \\
24 \\
15 \\
17 \\
31\end{array}$ & $\begin{array}{l}-0.009 \\
-0.0043 \\
-0.013 \\
-0.011 \\
-0.025 \\
-0.0106 \\
-0.012 \\
-0.013 \\
-0.011 \\
-0.009\end{array}$ & $\begin{array}{l}-4.27 \\
-2.42 \\
=5.85 \\
-5.06 \\
-10.6 \\
=4.91 \\
-5.46 \\
=5.85 \\
-5.06 \\
-4.6\end{array}$ & $\begin{array}{l}10 \% \mathrm{Mo}, \\
2 \% \mathrm{Mo}, \\
7.5 \% \mathrm{Mo}, \\
10.5 \% \mathrm{Mo}, \\
3.4 \% \mathrm{Mo}, \\
4 \% \mathrm{Mo}, \\
15 \% \mathrm{Mo}, \\
8 \% \mathrm{Mo}, \\
9 \% \mathrm{Mo}\end{array}$ & $\begin{array}{l}1700^{\circ} \mathrm{C},(\mathrm{S}) \\
1600^{\circ} \mathrm{C}, \\
1600^{\circ} \sim 1700^{\circ} \mathrm{C} \\
1606^{\circ} \mathrm{C},(\mathrm{S}) \\
1560^{\circ} \mathrm{C} \\
1600^{\circ} \mathrm{C},(\mathrm{S}) \\
1600^{\circ} \mathrm{C},(\mathrm{S}) \\
1600^{\circ} \mathrm{C} \\
1600^{\circ} \mathrm{C},(\mathrm{S}) \\
1580^{\circ} \sim 1680^{\circ} \mathrm{C}\end{array}$ \\
\hline V & $\begin{array}{l}\text { Pehlike \& Elliott } \\
\text { Narita \& MaKino } \\
\text { This study }\end{array}$ & $\begin{array}{l}13 \\
15\end{array}$ & $\begin{array}{l}-0.002 \\
-0.002 \\
-0.003\end{array}$ & $\begin{array}{l}-3.81 \\
=3.81 \\
-4.6\end{array}$ & $\begin{array}{l}15 \% \mathrm{~W} \\
15 \% \mathrm{~W} \\
9 \% \mathrm{~W}\end{array}$ & $\begin{array}{l}1606^{\circ} \mathrm{C},(\mathrm{S}) \\
1600^{\circ} \mathrm{C},(\mathrm{S}) \\
1580^{\circ} \mathrm{C},\end{array}$ \\
\hline
\end{tabular}

(L) : Levitation melting, (S ) : Sieverts' method

よぼす合金元素の影響を求めた. $1580^{\circ} \mathrm{C}$ に打けるこれ らの結果を総括し, 他の研究者の結果と比較してTable 6 に示す. これより, 本研究結果を含め, V, Cr, Mo お よび Wをとれぞれ添加した系の測定結果はほぼ一致し ていることがわかる．また本研究結果と著者らがさきに 測定した 12) 15 元素について，窒素の活量係数におよぽ す合金元素の影響をまとめて図示すると Fig. 14 およ びFig. 15 のようになる.

従来, 溶鉄中の水素, 炭素, 硫黄などの活量係数にお
よぽす合金元素の影響について多くの研究絬果が㩆售さ れ，これらの測定值より未測定元素の影留を推測する力 法として相互作用母係数と元素周期律との网連性などが 検討されている. 溶融 $\mathrm{Fe}-\mathrm{N}-\mathrm{j} 3$ 元系における相原作用 母係数 と元素周期律との関係については OHTANI と

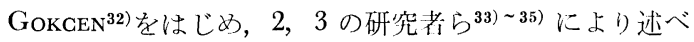
られているが，著者らの全測定值と SCHENCK ら 29) 37) 抢よび Sieverts 法ではあるが Pehlke ら ${ }^{13)}$ と Evans ら 36$)$ の一部の值をまとめると Fig. 16 のようになる. 


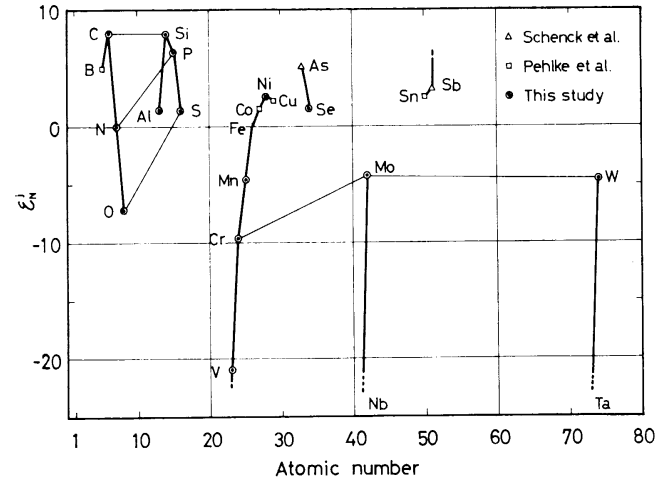

Fig. 16. Ralation between atomic number and interaction parameter of nitrogen $\varepsilon_{N}^{j}$ in liquid iron alloys at $1580^{\circ} \mathrm{C}$.

$\mathrm{Fe}-\mathrm{N}-\mathrm{j} 3$ 元系では第 2 , 第 3 短周期の元素群の相互作 用母係数 $\varepsilon_{\mathrm{N}}^{\mathrm{j}}$ は $\mathrm{N}_{\mathrm{a}}$ 族の $\mathrm{C}$ と $\mathrm{Si}$ に極大があり，また第

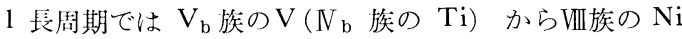
まで $\varepsilon_{\mathrm{N}}^{\mathrm{j}}$ 詣は順次增加する。このような傾向は著者らが さきに献告した浴融 Fe-S-j 3 元系 ${ }^{38)}$ の場合と同様であ る.

一般に浴液中の元素の活量は溶媒，溶質の各成分間の 相厉作用，溶液の構造，原子半径などを同時に考慮しな ければならない.しかし本研究で求めたいわゆる相互作 用母係数は $\mathrm{Fe}-\mathrm{N}-\mathrm{j} 3$ 元系溶融合金の溶解度の変化が $\mathrm{N}-\mathrm{j}$ 間の相互作用のみに起因するとして求めたものであ り，この值と原子の $\mathrm{N}$ と が窒化物を生成する標準自由 エネルギー変化 $\Delta G_{\mathrm{f}}^{\mathrm{o}}{ }^{39) 40)}$ との対応を検討してみる. こ の場合, 本研究の測定温度で安定な窒化物の $\Delta G_{\mathrm{f}}^{\circ}$ 值を 用い，窒素 1 原子当たりに換算した部分量 $\Delta \bar{G}_{\mathrm{f}}^{\circ}$ を用い た.これらの值を Table 7 に示し, 相互作用母係数 $\varepsilon_{\mathrm{N}}^{\mathrm{j}}$ と $\Delta \bar{G}_{\mathrm{f}}^{\circ}$ との䦥係を Fig. 17 に図示する. まず，遷 移元素群では Mo, Cr, V, Ta の $\varepsilon_{\mathrm{N}}^{\mathrm{j}}$ と $\Delta \bar{G}_{\mathrm{f}}^{\circ}$ が直線関 係を示し，さらに $\mathrm{N}$ 親和力の強い $\mathrm{Ti}$ は Taから折線 となつて大きく直線関係からずれるよらである，既報 の $\varepsilon_{\mathrm{N}}^{\mathrm{Ta}}$ の值 ${ }^{13) 36) 41)}$ は一致していないが， その中で森田 $ら^{41)}$ の実測值 $\varepsilon_{N}^{\mathrm{T} a}=-41.0$ が直線上に配列する. 他方, 還移元素以外の元素群では $\mathrm{B}, \mathrm{Al}, \mathrm{Si}, \mathrm{P}$ の 4 元素の $\Delta \bar{G}_{\mathrm{f}}^{\circ}$ が明らかで, $\mathrm{Si}, \mathrm{B}^{36) 42) 43)}, \mathrm{Al}$ は $\mathrm{N}$ と親和力の強 い順に配列している。しかしながら，遷移元素群とその 他の元素群では， $\Delta \bar{G}_{\mathrm{f}}^{\circ}$ が近い值を示していても，それ ぞれ買なる相関性を示すようである。

\section{5. 結言}

5 種の合金元素をそれぞれ含む 2 元系溶融鉄合金の窒. 素溶解度を $1580^{\circ} \sim 1680^{\circ} \mathrm{C}$ の範囲で測定し，これより
Table 7. Standard free energies of formation of nitrides.

\begin{tabular}{|c|c|c|c|}
\hline Element & Compound & $\begin{array}{l}J G_{\AA}^{\circ}, \mathrm{kcal} / \mathrm{mol} \\
\text { at } 1580^{\circ} \mathrm{C}\end{array}$ & $\Delta \bar{G}_{\mathrm{f}}^{\circ}, \mathrm{kcal} / \mathrm{atom}$ of $\mathrm{N}$ \\
\hline $\mathrm{C}$ & $\mathrm{BN}$ & -20.0 & -20.0 \\
\hline $\mathrm{Al}$ & AIN & -28.9 & -28.9 \\
\hline $\mathrm{Si}$ & $\mathrm{Si}_{3} \mathrm{~N}_{4}$ & -27.7 & -6.93 \\
\hline $\mathrm{P}$ & $\mathrm{P}_{3} \mathrm{~N}_{5}$ & $119 \cdot 0$ & 23.8 \\
\hline $\mathrm{Ti}$ & TiN & -38.4 & -38.4 \\
\hline $\mathrm{V}$ & $\mathrm{VN}$ & $\begin{array}{l}-4.44 \\
-\end{array}$ & -4.44 \\
\hline $\mathrm{Cr}$ & $\mathrm{CrN}$ & 5.77 & 5.77 \\
\hline $\mathrm{Fe}$ & $\mathrm{Fe}_{4} \mathrm{~N}$ & 18.1 & 18.1 \\
\hline $\mathrm{Zr}$ & $\mathrm{ZrN}$ & -45.7 & -45.7 \\
\hline Mo & MoN & 8.8 & 8.8 \\
\hline $\mathrm{Ta}$ & $\mathrm{TaN}$ & -20.8 & -20.8 \\
\hline
\end{tabular}

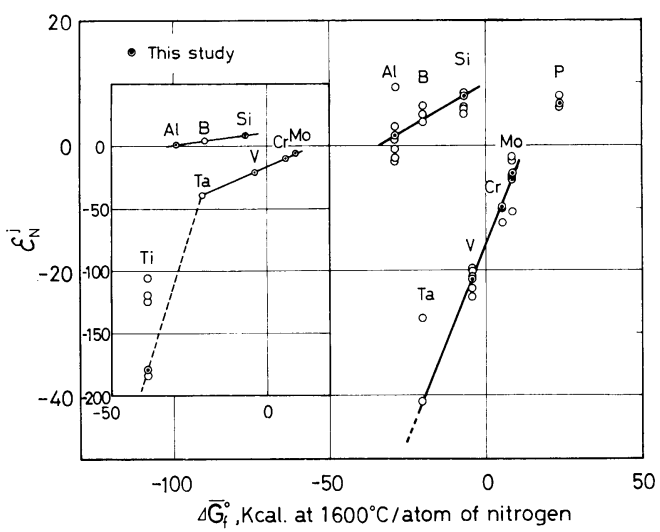

Fig. 17. Standard free energy of nitride formation $\Delta \vec{G}_{\mathrm{f}}^{\circ}$ and interaction parameter $\varepsilon_{\mathrm{N}}^{\mathrm{j}}$.

窒素の活量係数におよぼす合金元素の影響を求めた。そ の結果は Table 6 に示すよらになる。 また，これらの 結果と前報12) の結果を基にして, 元素周期律および窒化 物の標準生成自由エネルギー変化との関連性について若 干の考察を試みた。

終わりにあたり, 当時学部学生として研究遂行に協力 された日軽金·室伏好郎学士，日本 IBM ·海老澤猛学 土，東洋工業・清水勉修士および日新製鋼・斉藤孝雄学 土また有益な御助言を賜りました東北大学工学部教授 萬谷志郎博士の諸氏に深く感謝いたします。

\section{交献}

1) 石井不二夫，萬谷志郎，不破 祐：鉄と鋼， 68 (1982), p. 946

2 ) 石井不二夫, 萬谷志郎, 不破 祐：鉄と鋼, 68 (1982) 10, p. 1551

3 ) 森田善一郎, 国定尔治: 同上, 63(1977), p. 1663

4 ）前川静弥，中川義隆：同上，46(1960), p. 1438

5 ) M. M. Rao and N. Parlee: Memo. Sci. Rev. Met., 58 (1961), p. 52

$6)$ D. B. Evans and R. D. Pehlke: Trans. Met. Soc. AIME, 233(1965), p. 1620

$7) W . P$. Fischer, $H$. Frye, $H . J \cdot$ Fleischer, and $R$. Baum: Arch. Eisenhüttenw., 43(1972), p. 291 
8 ) A. N. Morozov, $V . F$. Isaev, and $L . G$. KoROLEv: Izv. Akad. Nauk SSSR, Metally, (1963) 4, p. 141

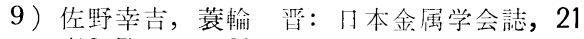
(1957), p. 569

10) R. M. Brick and $J . A$. Creevy: Metals Tech., 7 (1940) Tech. Pub., No. 1165

11) $V$. Kashyap and $N$. Parlee: Trans. Met. Soc. AIME, 212 (1958), p. 86

12）前川静弥，中川義隆：鉄之鋼，46(1960), p. 972

13) R. D. Pehlke and $J . F$. Elliott: Trans. Met. Soc. AIME, 218 (1960), p. 1088

14) N. M. E $E_{\mathrm{L}}$ TAyeb and $N$. PARlee: 同上, 227 (1963)，p. 929

15）成田貴一，牧野武久：神戸製鋼所, 中研第2087号 (1968)

16) 和田春枝, 郡司好喜, 和田次康：日本金属学会誌, 33 (1969), p. 720

17) $K$. Gunji, $K$. Sudō, and $E$. Ishikawa : The 4th Japan-USSR Joint Sym. on Phy. Chem. of Met. Processes (1973), p. 185

18) Yv. M. Pomarin, G. M. Grigorenko, and V. I. Lakomskir: Izv. Akad. Nauk SSSR, Metally, (1975) 5, p. 74

19) T. Saito: Sci. Rep. RITU, A-1 (1949), p. 419

20) T. Коотz: Arch. Eisenhüttenw., 15 (1941), p. 909

21) $H$. Wentrup and $O$. Reif: 同上, 20 (1949), p. 359

22) K. T. Kurochikin, P. V. Gel'd, and $V . I$. YavoIskir: Doklady Akad. Nauk SSSR, 84 (1952), p. 329

23) J. C. Humbert and $J$. F. Elliott: Trans. Met. Soc. AIME, 218 (1960), p. 1076

24) $P$. H. Turnock and $R$. D. Pehlke: 间上, 236 (1966), p. 1540

25）和田春枝，郡司好喜，和田次康：日本金属峃会誌， 32 (1968), p. 933

26) D. Cosma: Arch. Eisenhüttenw., 41 (1970), p. 195

27) V. I. Lakomskit, G. M. Grigorenko, G. F. Trokhov, and $Y u$. M. Pomarin: The 3rd
Japan-USSR Joint Sym. on Phy. Chem. of Met. Processes (1971), p. 72, Doklady Akad. Nauk Ukrain RsR., (1972) 3, p. 268, Izv. Akad. Nauk SSSR, Metally (1972) 4, p. 32

28) $H$. Wada and $R$. D. Pehlke: Met. Trans. B, 8B (1977), p. 443

29) $H$. Schenck, $M . G$. Frohberg, and $H$. Graf: Arch. Eisenhüttenw., 29 (1958), p. 673

30) $H$. Sahenck, $M . G$. Frohberg, and $H$. Heinemann: 间」:, 33 (1962), p. 593

31) $H$. WAdA and R. D. PehlKe: Met. Trans. B, 8B (1977), p. 675

32) M. Ohtani and N. A. Gokcen: Trans. Met. Soc. AIME, 218 (1960), p. 533

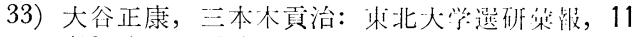
(1955), p. 217

34) E. T. Torkdogan, R. A. Hancock, $S . I$. Herlitz, and J. Dentan: JISI, 183 (1956), p. 69

35) $F$. Neumann and $H$. Schenck: Arch. Eisenhü ttenw., 30 (1959), p. 477

36) D. B. Evans and R. D. Pehlke: Trans. Met. Soc. AIME, 230 (1964), p. 1657

37) $H$. Sahenck, $M . G$. Frohberg, and $H$. Graf: Arch. Eisenhüttenw., 30 (1959), p. 533

38) 石井不二夫，不破 鿆：鉄と鎆，67 (1981), p. 746

39) J. F. Elliott and M. Gleiser: Thermochemistry for Steelmaking, 1 (1959) [AddisonWesley]

40) $O . R$. Stull and $H$. Prophet: JANAF thermochemical tables, 2nd ed. (1971)

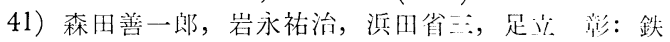
と鋼, 59 (1973), p. 214

42) $H$. Sahenck and $E$. Steinmetz: Arch. Eisenhüttenw., 39 (1968), p. 255

43) $V . F$. Isaev and $A . N$. Morozov: Izv. Ak ad. Nauk SSSR, Metally (1964), 2, p. 13

44) J. Chipman: JISI, 180 (1955), p. 97

45) 的㙐幸雄, 不破 祐：学振 19 委-No. 5593 (环和 34 年 7 月)

46) 不破 祐, 不井不二夫：学振 19 委-No. 7941 (将 和 40 年 9 月) 